\title{
High Tannin Sorghum in Diets of Japanese Quails (Coturnix coturnix japonica)
}

Author(s)

Faquinello $P$

Murakami AE

Cella PS

Franco JRG

Sakamoto MI

Bruno LDG

Departamento de Zootecnia

Universidade Estadual de Maringá - UEM

\section{Mail Address}

Departamento de Zootecnia

Universidade Estadual de Maringá - UEM

Avenida Colombo, 5790 - Zona 07

87.020-900 - Maringá, PR

\section{Keywords}

Coturnix coturnix japonica, performance, sorghum, tannin, yolk color.

\section{ABSTRACT}

This experiment was carried out to evaluate the effects of replacing corn by high tannin sorghum in diets of japanese quails (Coturnix coturnix japonica) on performance and egg quality. Two hundred and fifty-two quails with 50 weeks of age were evaluated during four periods of 21 days. The treatments consisted of diets containing 20,40,60, 80 and $100 \%$ of sorghum, and a control treatment ( $100 \%$ of corn). Diets were formulated so that the levels of energy, protein, amino acids (methionine+cystine and lysine), calcium and phosphorus were similar A completely randomized experimental design was used, with six treatments, six replicates and seven quails for experimental unit. Evaluated parameters were egg production (\%), feed intake, feed: gain ratio (kg/ $\mathrm{kg}$ and $\mathrm{kg} /$ dozen), egg mass ( $\mathrm{g}$ ), egg weight and egg quality (Haugh unit, eggshell percentage, shell thickness and yolk color). The increasing sorghum levels had a negative linear effect $(p<0.05)$ on egg production $\left(Y=82.9138-0.0966553 X ; R^{2}=0.87\right)$, egg mass $(Y=8.0840626-$ $\left.0.009336932 X ; R^{2}=0.80\right)$ and yolk color $(Y=7.14340-0.0546875 X$; $\left.R^{2}=0.98\right)$. On the other hand, the replacement had a positive linear effect on feed:gain ratio expressed as $\mathrm{kg} / \mathrm{kg}(\mathrm{Y}=0.372174+0.000536191 \mathrm{X}$; $\left.R^{2}=0.92\right)$ and as $\mathrm{kg} /$ dozen $\left(Y=2.71516+0.00423485 X ; R^{2}=0.94\right)$. Control treatment means were different by Dunnett's test $(p<0.05)$ for egg mass (g) when compared to the treatment with 100\% of replacement and for yolk color when compared to treatments containing 20,40,60, 80 and $100 \%$ of sorghum. There were no differences ( $p>0.05$ ) in feed intake, egg weight, Haugh unit, eggshell percentage and shell thickness. In conclusion, up to $80 \%$ of high tannin sorghum may be used on diets if xanthophyll pigments are added in order to maintain the commercial quality of final products.

\section{INTRODUCTION}

The increasing use of corn in animal feeding has resulted in a competition with its use in human feeding. Besides, corn production and commercialization have been frequently influenced by the government's economic policies, and have been subjected to variations depending on availability and price (Whitaker \& Carvalho, 1997).

Several researches have evaluated substitutes for corn and, in this situation the use of uncommon food ingredients in animal diet formulation must be better appraised. For such evaluations, the nutritional value of the food, the best inclusion level in diets and economic viability should be considered (Nascimento, 1997). One of the optional ingredients is sorghum.

Virtually all produced sorghum is used for either human or animal feeding. In developing countries, sorghum is broadly used in human feeding; in developed countries, however, almost all sorghum is used as 
Faquinello $P$, Murakami AE, Cella PS, Franco JRG, Sakamoto MI, Bruno LDG forage for animals and a small remaining portion is used to obtain by-products (Rostagno, 1976).

In poultry nutrition, sorghum grains are being studied as a possible energy substitute for corn, based on the similarity of their chemical compositions. Sorghum has smaller levels of dry matter but, on the other hand, corn contains more fat than sorghum. The other nutrient levels of the two cereals are similar (Rostagno et al., 2000).

A factor that must be considered when using sorghum grains in animal nutrition is the presence of phenolic substances (tannins), which limit large-scale use. If, on the one hand, the high tannin contents in the seed reduce the damages caused by birds to the culture due to the astringent flavor, on the other, the seeds become also less palatable and nutritive, since tannin interferes with the metabolism of carbohydrates and proteins (Rostagno et al., 1973). The level of tannin in sorghum grains varies from 1.3 to $3.6 \%$ in high tannin sorghum and from 0.1 to $0.7 \%$ in low tannin sorghum (Myer et al., 1986).

Several studies have shown that sorghum with low tannin levels may partially or totally replace corn in bird diets without affecting weight gain, feed intake, feed:gain ratio, carcass yield, quality of eggs and reproductive performance (Hulan \& Proudfoot, 1982; Santos et al., 1982; Castro \& Costa, 1984; Streeter et al., 1991; Louis et al., 1997). On the other hand, Rostagno et al. (1973) and Armstrong et al. (1973) reported lower weight gain and poorer feed:gain ratio in broiler chickens fed diets containing high tannin sorghum grains with protein levels of $14-16 \%$.

Corn was substituted by sorghum in initial and final broiler diets and no differences were seen for weight gain, feed intake and feed:gain ratio (Lopez et al., 1974, Trinidade et al., 1974). It was concluded that the replacement viability is determined by the economic situation (prices of the different ingredients), and it is also necessary to add pigments to the diets, since consumers prefer carcasses with more yellowish coloration.

Malik \& Quisenberry (1963) replaced corn with sorghum in laying hen diets. At 75 and 100\% substitution levels, it was detected a decrease in egg production, egg weight and yolk pigmentation. When sorghum was used at $50 \%$, values similar to the control group (100\% corn) were obtained for egg production, egg weight and pigmentation. Bonnino \& Mazza (1971) reported decrease in egg weight and worse feed: gain ratio when corn was totally substituted by low tannin sorghum; however, sorghum did not affect egg production.
High Tannin Sorghum in Diets of Japanese Quails (Coturnix coturnix japonica)

Better results were obtained for laying hens when $50 \%$ of the corn was replaced by low-tannin sorghum in diets, with no differences in mortality, egg weight and feed:gain ratio (Costa et al., 1974). These results agree with Bornstein \& Bartov (1967), who compared the performance of laying hens fed with corn, cornsorghum (50-50\%) and sorghum. There were no differences in egg production and feed: gain ratio among treatments.

Bonnino et al. (1980) used sorghum with high tannin and $16 \%$ of crude protein in the diet of laying hens and reported that egg production was lower in diets containing low tannin sorghum (72 and $77 \%$, respectively). Birds fed diets based on high tannin sorghum presented lower egg production and poorer feed:gain ratio when compared to birds fed diets with low tannin sorghum or the corn-based basal diet (Armanious et al., 1973).

Considering the importance of this alternative ingredient in non-ruminant feeding, this work evaluated the effects of the substitution of sorghum for corn in diets of Japanese quails (Coturnix coturnix japonica), at different levels, on performance and egg quality.

\section{MATERIAL AND METHODS}

The experiment was carried out at Universidade Estadual de Maringá, from July $20^{\text {th }}$ to October $08^{\text {th }}$, 2002. Two hundred and fifty-two Japanese quails (Coturnix coturnix japonica) were used. The experiment lasted for four periods of 21 days during the laying phase (second production cycle), starting when the birds were 50 weeks of age. They were distributed in a completely randomized design with six treatments, six repetitions and seven quails per experimental unit.

Diets were formulated according to the nutritional requirements of NRC (1994), considering the composition of ingredients according to Rostagno et al. (2000). Treatments consisted of a control treatment $(100 \%$ of corn) and treatments in which corn was replaced by sorghum with high tannin, at levels of 20,40,60, 80 and $100 \%$. The diets had similar levels of metabolizable energy $(\mathrm{kcal} / \mathrm{kg})$, crude protein, methionine+cystine, lysine, calcium and available phosphorus (Table 1). The tannin level of sorghum grains was $1.44 \%$ as determined by the Prussian blue method.

Quails were housed in galvanized wire cages with $24 \times 38 \times 15 \mathrm{~cm}$ of width, length and height, respectively. Experimental diets were given ad libitum and an adaptation period of three days was considered. Natural and artificial lighting was used, with a total of 17 hours 


\begin{tabular}{|c|c|c|c|c|c|c|}
\hline \multirow[t]{2}{*}{ Ingredients } & \multicolumn{6}{|c|}{ Sorghum level (\%) } \\
\hline & 0 & 20 & 40 & 60 & 80 & 100 \\
\hline Corn, grain & 57.68 & 45.06 & 32.05 & 19.23 & 6.43 & - \\
\hline Soybean meal & 32.86 & 33.04 & 33.30 & 33.52 & 33.74 & 33.85 \\
\hline Sorghum & - & 11.51 & 23.07 & 34.61 & 46.15 & 51.94 \\
\hline Soybean oil & 1.98 & 2.98 & 4.05 & 5.10 & 6.14 & 6.66 \\
\hline Dicalcium phosphate & 1.36 & 1.36 & 1.37 & 1.37 & 1.37 & 1.37 \\
\hline Limestone & 5.30 & 5.30 & 5.31 & 5.31 & 5.30 & 5.30 \\
\hline Sodium chloride & 0.35 & 0.35 & 0.37 & 0.37 & 0.38 & 0.38 \\
\hline DL-Methionine & 0.11 & 0.12 & 0.12 & 0.13 & 0.14 & 0.14 \\
\hline L-Lysine $\mathrm{HCl}$ & 0.03 & 0.03 & 0.03 & 0.03 & 0.03 & 0.03 \\
\hline Mineral supplement & 0.07 & 0.07 & 0.07 & 0.07 & 0.07 & 0.07 \\
\hline Vitamin supplement $^{2}$ & 0.25 & 0.25 & 0.25 & 0.25 & 0.25 & 0.25 \\
\hline Antioxidant & 0.01 & 0.01 & 0.01 & 0.01 & 0.01 & 0.01 \\
\hline Total & 100.00 & 100.00 & 100.00 & 100.00 & 100.00 & 100.00 \\
\hline \multicolumn{7}{|c|}{ Calculated Composition } \\
\hline M.E. (kcal/kg) & 2,900 & 2,900 & 2,900 & 2,900 & 2,900 & 2,900 \\
\hline Crude protein (\%) & 20.00 & 20.00 & 20.00 & 20.00 & 20.00 & 20.00 \\
\hline Lysine (\%) & 1.08 & 1.08 & 1.08 & 1.08 & 1.08 & 1.08 \\
\hline Methionine + Cystine (\%) & 0.74 & 0.74 & 0.74 & 0.74 & 0.74 & 0.74 \\
\hline Calcium (\%) & 2.50 & 2.50 & 2.50 & 2.50 & 2.50 & 2.50 \\
\hline Available phosphorus (\%) & 0.36 & 0.36 & 0.36 & 0.36 & 0.36 & 0.36 \\
\hline \multicolumn{7}{|c|}{ 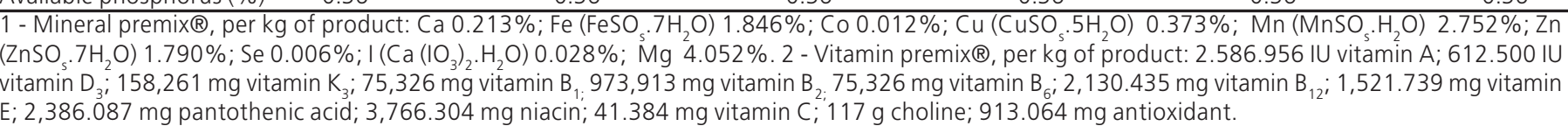 } \\
\hline
\end{tabular}

of light. Maximum and minimum temperatures recorded during the experiment were $24.02^{\circ} \mathrm{C}$ and $18.56^{\circ} \mathrm{C}$, respectively.

Eggs were collected daily and egg production per cage was determined. On the $21^{\text {st }}$ day of each period, feed intake ( $\mathrm{g} / \mathrm{bird} / \mathrm{day})$ and feed: gain ratio of the period were determined $(\mathrm{kg} / \mathrm{kg}$ and $\mathrm{kg} / \mathrm{dozen})$. In the last four days of each period, eggs were weighed $(\mathrm{g} \pm 0.01)$ to determine mean egg weight, and a sample of three eggs of each replicate was broken to evaluate internal egg quality, calculated as follows and expressed in Haugh unities: U.H. $=[100 x$ log (albumen height $+7.57-1.7 x$ egg weight $\left.{ }^{0.37}\right)$ ]. Yolk color was determined using the colorimetric fan from Roche ${ }^{\circledR}$, which includes yolk colors that are produced under normal feeding conditions.

To determine eggshell percentage, eggshells were washed and dried at environmental temperature for 48 hours. After drying, they were weighed and eggshell percentage (\%) was calculated in relation to egg weight. After eggshell percentage was determined, thickness was measured using a manual micrometer (Mitutoyo ${ }^{\circledR}$ ), with resolution of $0.1 \mathrm{~mm}$.

Final data were submitted to polynomial regression analysis using the statistical software SAEG (1982). Results of treatments fed with the control diet and with each of the different levels of sorghum were compared by the Dunnett's test ( $5 \%)$.

\section{RESULTS AND DISCUSSION}

The results of production performance of Japanese quails (Coturnix coturnix japonica) fed with diets containing different levels of sorghum are shown in Table 2. There was a linear decrease $(p<0.05)$ in egg production with increasing levels of sorghum in diets $\left(Y=82.9138-0.0966553 X ; R^{2}=0.87\right.$; Figure 1). These results are in agreement with Armanious et al. (1973) and Malik \& Quisenberry (1963), who replaced corn for sorghum in laying hen diets at levels of 75 and $100 \%$ and detected a decrease in egg production, egg weight, and yolk pigmentation. When $50 \%$ of the corn was replaced by sorghum, values similar to the control group were obtained for egg production, egg weight and pigmentation. Bornstein \& Bartov (1967) and Bonnino \& Mazza (1971) did not report differences in egg production among the experimental treatments.

Feed: gain ratio was poorer with the increase in sorghum levels in diet; a linear increase $(p<0.05)$ in feed: gain ratio was seen when expressed as $\mathrm{kg} / \mathrm{kg}$ $\left(Y=0.372174+0.000536191 X ; R^{2}=0.92\right)$ and as $\mathrm{kg} /$ dozen $\left(Y=2.1516+0.00423485 X ; R^{2}=0.94\right)$ (Figures 2 and 3). Malik \& Quisenberry (1963) and Costa et al. (1974) concluded that up to $50 \%$ of the corn might be replaced by sorghum with no negative effects on the feed/egg production ratio. However, the results are 
Faquinello $P$, Murakami AE, Cella PS, Franco JRG, Sakamoto MI, Bruno LDG

Table 2 - Performance of quails feed diets containing different levels of high tannin sorghum.

\begin{tabular}{|c|c|c|c|c|c|c|c|c|}
\hline \multirow[t]{2}{*}{ Parameters } & \multicolumn{6}{|c|}{ Inclusion levels of sorghum (\%) } & \multirow[t]{2}{*}{ CV (\%) } & \multirow[t]{2}{*}{ Regression } \\
\hline & 00 & 20 & 40 & 60 & 80 & 100 & & \\
\hline$\%$ Egg production ${ }^{1}$ & 81.46 & 80.07 & 79.99 & 79.11 & 79.97 & 72.42 & 7.55 & $Y=82.9138-0.0966553 X ; R^{2}=0.87$ \\
\hline Feed intake (g/bird/day) ${ }^{1}$ & 26.66 & 26.87 & 26.99 & 26.33 & 26.52 & 25.88 & 5.24 & ns \\
\hline Feed: gain ratio (kg/dozen) ${ }^{1}$ & 0.3961 & 0.3822 & 0.3986 & 0.3965 & 0.4189 & 0.4256 & 7.87 & $Y=0.372174+0.000536191 X ; R^{2}=0.92$ \\
\hline Feed: gain ratio $(\mathrm{kg} / \mathrm{kg})^{1}$ & 2.905 & 2.821 & 2.894 & 2.908 & 3.065 & 3.159 & 7.68 & $Y=2.71516+0.00423485 X ; R^{2}=0.94$ \\
\hline Egg weight (g) & 11.37 & 11.23 & 11.40 & 11.39 & 11.52 & 11.28 & 2.45 & ns \\
\hline Haugh Unit & 88.08 & 87.39 & 87.74 & 87.47 & 87.18 & 87.41 & 1.26 & ns \\
\hline Eggshell (\%) & 7.49 & 7.60 & 7.56 & 7.67 & 7.49 & 7.68 & 2.94 & ns \\
\hline Eggshell thickness (mm) & 0.1994 & 0.1957 & 0.1918 & 0.1982 & 0.1926 & 0.1990 & 3.18 & ns \\
\hline Yolk color & 6.24 & $5.74^{*}$ & $5.15^{*}$ & $4.22^{*}$ & $2.71 *$ & $1.49 *$ & 6.78 & $Y=7.14340-0.0546875 X ; R^{2}=0.98$ \\
\hline Egg mass $(g)^{1}$ & 9.262 & 8.992 & 9.119 & 9.011 & 9.213 & $8.169 *$ & 7.23 & $Y=8.0840626-0.009336932 X ; R^{2}=0.80$ \\
\hline
\end{tabular}

1 - linear effect $(p<0.05)$. Means are different from control by the Dunnet Test $(p<0.05)$.

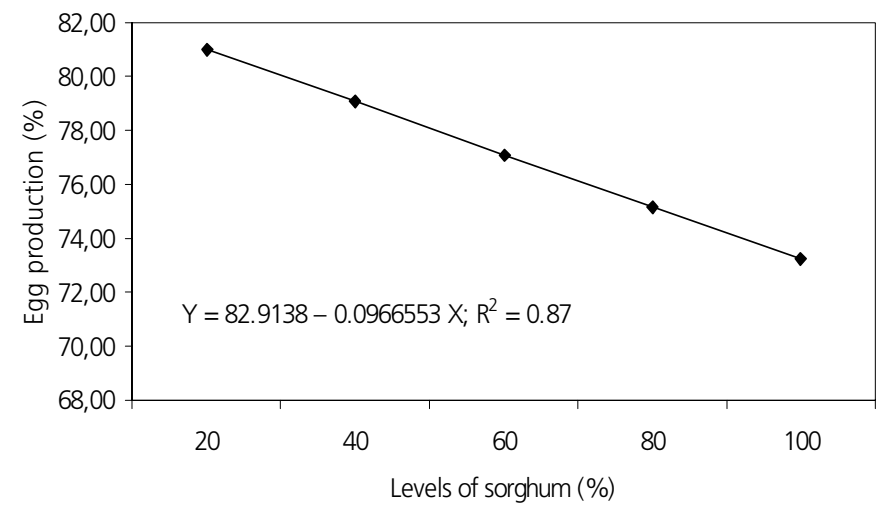

Figure 1 - High tannin sorghum on the egg production of Japanese quails.

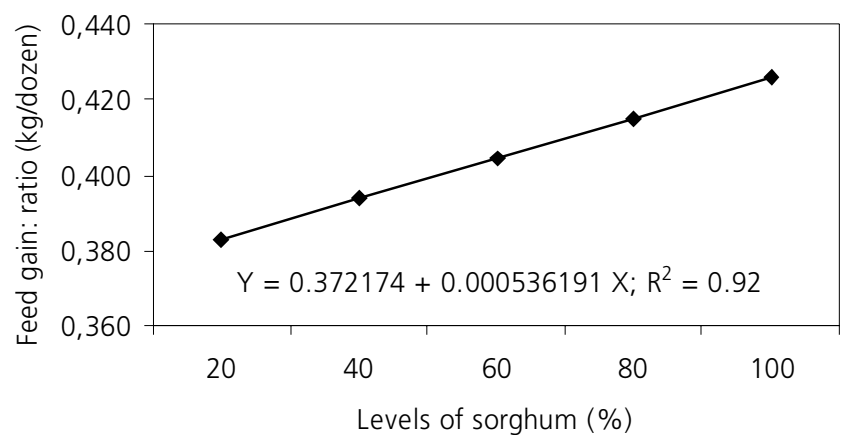

Figure 2 - High tannin sorghum on the feed: gain ratio ( $\mathrm{kg} / \mathrm{dozen})$ of Japanese quails.

different from results reported by Chavez et al. (1966), Bornstein \& Bartov (1967) and Armanious et al. (1973), who found no differences on feed: gain ratio.

Tannins were shown to reduce weight gain and apparent digestibility of nitrogen, amino acids and, to some extent, energy in the growth of non-ruminants,

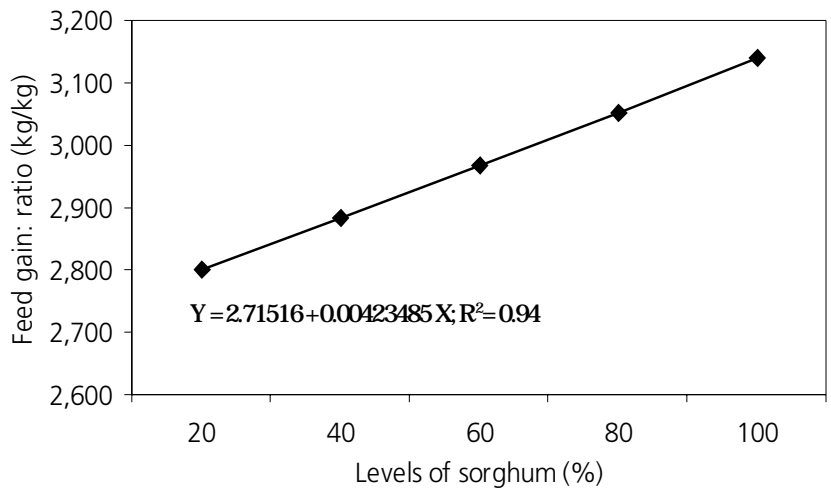

Figure 3 - High tannin sorghum on the feed: gain ratio $(\mathrm{kg} / \mathrm{kg})$ of Japanese quails.

besides compromising the efficiency of feed: gain ratio (Jansman, 1993). However, literature information about the influence of tannin on feed intake is conflicting.

The results showed a linear decrease $(p<0.05)$ in egg mass ( $g$, Figure 4) with increasing sorghum levels in the diets $\left(Y=8.0840626-0.009336932 X ; R^{2}=0.80\right)$. No differences were seen by Dunnett's test $(p>0.05)$ in quails fed with levels of $20,40,60$ and $80 \%$ of sorghum, only the group fed $100 \%$ of sorghum showed differences $(p<0.05)$ when compared to the control group.

The regression analysis showed a linear decrease $(p<0.05)$ in yolk coloration $(Y=7.14340-0.0546875 X$; $R^{2}=0.98$; Figure 5) with the increase of sorghum levels in diets. Such result was expected and several authors reported that sorghum has low carotenoid levels, which requires the inclusion of synthetic pigments in diets, so that the commercial quality of eggs is preserved (Armanious et al., 1973; Belyiavin \& Marangos, 1988). There were differences $(p<0.05)$ in the yolk coloration of eggs produced by quails fed with $20,40,60,80$ 
Faquinello $P$, Murakami AE, Cella PS, Franco JRG, Sakamoto MI, Bruno LDG
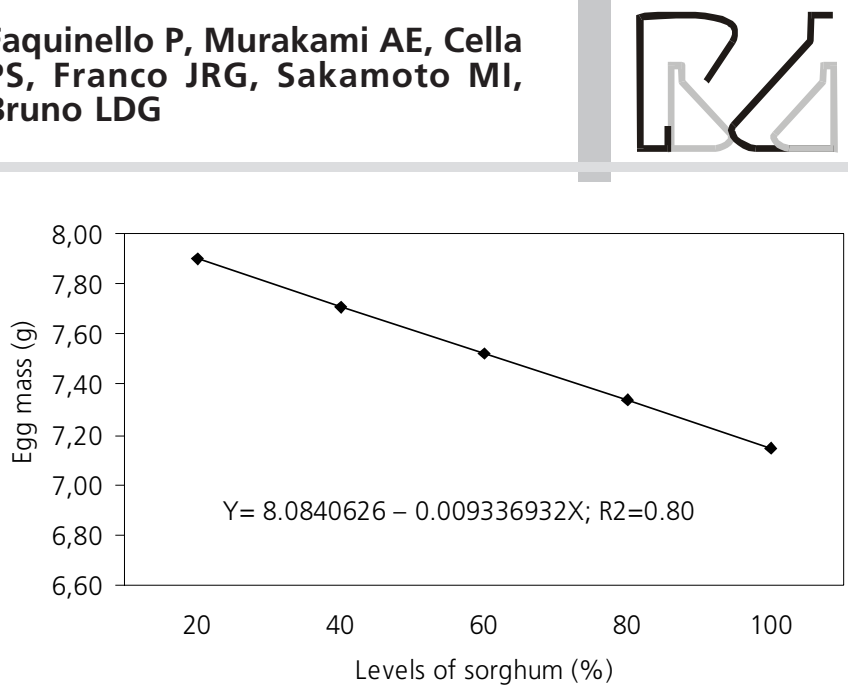

Figure 4 - Egg mass (g) produced by Japanese quails fed different levels of high tannin sorghum in the diet.

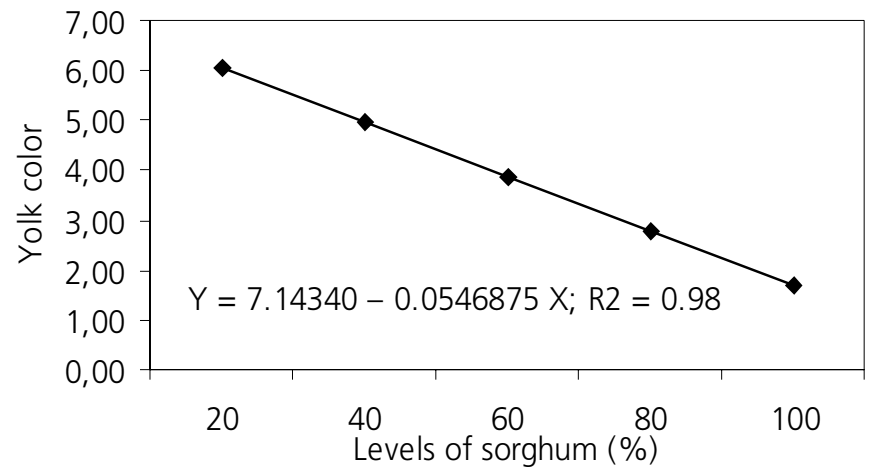

Figure $\mathbf{5}$ - Yolk color of eggs produced by Japanese quails fed different levels of high tannin sorghum in the diet.

and $100 \%$ of sorghum, when compared to the control group, probably due to the absence of xanthophylls in sorghum, which are responsible for the yellowish coloration of the yolk. These results corroborate the results reported by Malik \& Quisenberry (1963).

Differences were not seen ( $p>0.05$ ) for feed intake, egg weight, Haugh unit, eggshell percentage and eggshell thickness. Costa et al. (1974) found no differences in mean egg weight when laying hens were fed with diets containing sorghum as corn substitute at levels of 50 and 100\%. Malik \& Quisenberry (1963) observed a decrease in egg weight when 75 and $100 \%$ of the corn in the diet was substituted; values were similar to the control group only when $50 \%$ of sorghum was used.

In spite of the high tannin level in the sorghum grains that were used (1.44\%), no effects were seen on feed intake. This result showed that Japanese quails are more resistant to the effects of the astringent flavor of tannins added to the diet.

\section{CONCLUSIONS}

High Tannin Sorghum in Diets of Japanese Quails (Coturnix coturnix japonica)

High tannin sorghum may replace corn at up to $80 \%$ in diets if a source of xantophyll pigments is added to the diets in order to maintain the commercial quality of the products. The final decision to replace corn by sorghum will be determined based on price and availability of this product.

\section{REFERENCES}

Armanious MW, Britton WM, Fuller HL Effect of methionine and choline on tannic acid and tannin toxicity in the laying hen. Poultry Science 1973; 52(6):2160-2168.

Armstrong WD, Featherston WR, Rogler JC. Influence of methionine and other dietary additions on the performance of chicks fed bird resistant sorghum grain diets. Poultry Science 1973; 52(4):15921599

Belyiavin CG, Marangos AG. Natural products for egg yolk pigmentation. In: Cole DJA, Haresign W (Eds.); 1988. Recent developments in poultry nutrition. London: Butteworths, 1988; p.239-260.

Bonnino MF, Azcona JO, Sceglio O. The effect of ammoniation, methionine and gluten meal supplementation on the performance of laying hens fed high tannin sorghum grain diets. In: Proceedings of the $6^{\text {th }}$ European Poultry Conference; 1980; p.481-488.

Bonnino M, Mazza M. Valor substitutito del maíz colorado, dentado y sorgo en raciones para gallinas ponedoras. Boletín Divulgación Tecnica. 6, INTA, 1971; p 4.

Bornstein S, Bartov I. Comparisons of sorghum grain and maize as the principal cereal grain source in poultry rations. British Poultry Science 1967; 8:223-230.

Castro LFV, Costa P. Estudo da substituição do milho pelo sorgo em dietas de galinhas poedeiras. Revista Portuguesa de Ciências Veterinárias de Lisboa 1984; 79(472):281-290.

Chavez R, Matheu PJ, Reid BL. Grain sorghum in laying hen diets. Poultry Science 1966; 45(6):1275-1283.

Costa PTC, Peishel A, Stiles, D. Avaliação de milho x sorgo com e sem farinha de peixe em dietas de poedeiras industriais. In: 11 Reunião da Sociedade Brasileira de Zootecnia, 1974, Anais... Sociedade Brasileira de Zootecnia, 1974; p. 205-206.

Hulan HW, Proudfoot FG. Nutritive value of sorghum grain for broiler chickens. Canadian Journal of Animal Science 1982; 62:869-875.

Jansman AJM. Tannins in feedstuffs for simple-stomached animals. Nutrition Research Reviews 1993; 6:209-236.

Lopez J, Trindade DS, Munarsky I, Oliveira SC, Cavalheiro ACL, Sebastião JM. Substituição parcial do milho por sorgo na criação

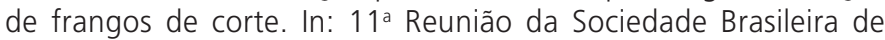
Zootecnia. Fortaleza. 1974. Anais... Fortaleza: Sociedade Brasileira de Zootecnia, 1974; p. 212-213. 
Louis GF, Lewis AJ, Peo ER. Feeding value of grain sorghum for the lactating sow. Journal of Animal Science 1997; 69(1):223-229.

Malik DP, Quisenberry JH. Effects of feeding various milo, corn and protein levels on laying house performance of egg production stock. Poultry Science 1963; 42(3):625-633.

Myer RO, Gorbet DW, Combs GE. Nutritive value of high and lowtannin grain sorghums harvested and stored in the high-moisture state for growing-finishing swine. Journal of Animal Science 1986; 62(3):1290-1297.

Nascimento AH. Avaliação química e energética do farelo de canola e sua utilização para frangos de corte. [Dissertação]. Viçosa (MG): Universidade Federal de Viçosa; 1997.

NRC - National Research Council. Nutrient Requirements of Poultry. Washington, D.C., National Academy Press, $9^{\text {th }}$ revised edition, 1994, 155p.

Rostagno HS, Featherston WR, Rogler JC. Studies on the nutritional value of sorghum grains with varying tannin contents for chicks. 1. Growth studies Poultry Science 1973; 52(2):765-772

Rostagno HS. Comentários sobre o uso do sorgo na ração para aves. Revista Brasileira de Zootecnia. 1976; 5:119-140.

Rostagno HS, Silva DJ, Costa PM. Composição de alimentos e exigências nutricionais de aves e suínos. (Tabelas Brasileiras). Ed. Imprensa Universitária. Viçosa, MG. 2000, 139 p.

SAEG - Sistema para análise estatística e genética Universidade Federal de Viçosa - UFV. Central de Processamento de Dados UFV - CPD. Viçosa, MG. 1982, 59 p.

Santos JBO, Viana SP, Monteiro ES. Emprego do sorgo na alimentação de suínos com verificação do seu valor biológico em comparação ao milho. In: Reunião da Sociedade Brasileira de Zootecnia, 19.1982, Piracicaba. Anais... Piracicaba: Sociedade Brasileira de Zootecnia. Piracicaba, 1982.

Streeter MN, Wagner DG, Hibberd CA. Comparison of corn with four sorghum grain hybrids: site and extent of digestion in steers. Journal of Animal Science 1991; 68(10):3429-3440.

Trindade DS, López J, Oliveira M, Cavalheiro ACL. Substituição parcial do milho pelo sorgo e pela farinha de mandioca em rações para frango de corte. Revista Brasileira de Zootecnia 1974; 3(1):1329.

Whitaker HMA, Carvalho RLO. Substituição do milho pelo sorgo em rações para eqüinos. Revista Brasileira de Zootecnia 1997; 26(1):139-143. 